Лисничук Антонина, Панасенко Руслана, Вериковский Леонид. Характеристика возрастных деревьев Кременецкого ботанического сада по количественным и качественным признакам. На территории парка, с которого берет начало Кременецкий ботанический сад, растет 93 экземпляра деревьев 14 видов трех категорий: потенциально возрастные, возрастные и многовековые. Средние показатели возраста варьируют в пределах от 114 до 202 лет с максимальной отметкой 245 лет, высоты деревьев от 19 до 34 м, диаметра кроны от 5 до 12 м, диаметра ствола - от 43, 9 до 98,7 см. Показатели высоты деревьев варьируют в пределах 21-36 м, диаметра кроны - 4-15 м, диаметра ствола - 21-126 см. Деревья высажены во времена Иезуитского коллегиума, особой академической школы, в период функционирования ботанического сада как составной части Волынской гимназии и Кременецкого лицея с учительской семинарией и гимназией им. Чацкого. За санитарным состоянием к первой категории (без признаков ослабления) отнесены 32 дерева $(34,0 \%)$. Высокоэстетичными качествами обладают 53 дерева $(57,0 \%)$. Такие деревья имеют природоохранную, научную, историческую, педагогическую, рекреационную ценности, поэтому нуждаются в неотложных мерах по сохранению и содержанию.

Ключевые слова: возрастные деревья, возрастные категории, морфометрические показатели, санитарное и эстетическое состояния.

Lisnichuk Antonina, Panasenko Ryslana, Verykivskyi Leonid. Characteristic of the old Trees in Kremenets Botanical Garden According to Their Quantitative and Qualitative Criteria. Assessment of the venerable dendroflora condition on kremenets botanical garden park territory. 93 copies of 14 species of trees grow at present on the park territory from which Kremenets botanical garden takes its beginning. They are of threecategories: potentially oldaged,old-aged and centuries-old. The average age rangesfrom 114 to 202 years with a peak of 245 years, the tree height is from 19 to 34 meters, diameter of the crown varies from 5 to $12 \mathrm{~m}$, trunk diameter - from 43,9 to $98,7 \mathrm{~cm}$.

Height of trees is from 21 to $36 \mathrm{~m}$, diameter of crown ranges from 4 to $15 \mathrm{~m}$, diameter of trunk extends from 21 to $126 \mathrm{~cm}$. The trees were planted in the days of the Jesuit collegium, a special academic school, in the period of the botanical garden functioning as a component part of theVolyn High school and Kremenets Lyceum with teachers'seminary and High School named after Chatsky. The sanitary condition of the first category (with no signs of weakening) includes 32 trees $(34,0 \%)$. Highly aesthetic features were testified to 53,0 trees $(57,0 \%)$. These trees have environmental, scientific, historical, educational, recreational values, therefore taking urgent measures for their conservation and maintenance is needed.

Key words: ancient trees, age categories, biometric indicators, sanitary and aesthetic conditions.

Стаття надійшла до редколегії 29.09.2016 р.

УДК 581.1:58.02

\title{
Лариса Сергєєва,
} Лариса Броннікова

\section{Пролін-опосередковані реакції тютюну на дію засолення}

Предметом роботи стало порівнянне дослідження реакцій тютюну за дії летального засолення та ролі вільного проліну в реалізації солестійкості.

Методом клітинної селекції з використанням летальних для клітинних культур доз катіонів $\mathrm{Ba}^{2+}$ отримано стійкі клітинні лінії тютюну. Із них отримано регенеранти R0, а також насіннєві покоління R1, R2. Клітинні лінії й рослини R0, R1 та R2 вирізнялися стійкісттю до модельованого летального сольового стресу. Порівнювали реакції, спряжені з підвищенням рівня вільного проліну, в експериментально отриманних рослин і вихідних рослин тютюну, який $є$ типовим глікофітом. Рослини R0 культивували in vitro протягом 35 діб у присутності 20,0 г/л солей морської води, рослини R1, R2 тестували у водній культурі 10 діб, додаючи 25,0 г/л тієї ж речовини.

Відзначали протилежні реакції рослин тютюну у відповідь на дію засолення: контрольні рослини гинули, а експериментальні варіанти стабілізували свій метаболізм, що проявлялось у збереженні синтезу білка. Водночас у всіх рослинах зростав уміст вільного проліну. Однак акумуляція цієї амінокислоти в експериментальних варіантах була наслідком підвищення іiі синтезу, тоді як пролін у контрольних рослинах утворювався при деградації клітинних білкових компартментів. Отже, абсолютне значення вмісту вільного проліну не може бути гарантованим показником солестійкості, потрібно оцінювати динаміку його змін.

Ключові слова: тютюн, клітинна селекція катіони барію, засолення, стійкість, пролін.

(ㄱ Сергєєва Л., Броннікова Л., 2016 
Постановка наукової проблеми та їі значення. Серед абіотичних чинників довкілля засолення вважається одним із найбільш агресивних, оскільки спектр патологічних змін у рослині, яка зазнає його дії, викликаний сумісною дією іонного, осмотичного та оксидативного стресів. Водночас кількість уражених земель постійно збільшується внаслідок вторинного засолення, а зміни кліматичних умов перетворюють прісну воду в багатьох регіонах на продукт підвищеного дефіциту навіть для населення. Отже, отримання рослинних форм із підвищеним рівнем солестійкості є напрямом активного наукового спрямування.

Досягнення успіху можливе лише за умови вибору незаперечних показників, спряжених із солестійкістю. Відомо, що природні галофіти характеризуються фізіологічними особливостями, пов'язаними 3 акумуляцією вільного проліну $[1 ; 2]$. Водночас існує чимало даних, які вказують на відсутність кореляції між солестійкістю та підвищенням умісту проліну [2]. Отже, ця проблема ще далека від повного розв'язання, а тому потребує висування нових гіпотез і випробування нових підходів. Потрібно враховувати також вибір об'єкта дослідження, дози стресового чинника, тривалості стресового впливу. Стосовно проблеми солестійкості виключно цікавим $є$ отримання стійких рослин, беручи за основу чутливі варіанти. Порівнянний аналіз реакцій обох форм на дію стресу зробить суттєвий внесок у формування загальної концепції стресу / стійкості.

Аналіз досліджень цієї проблеми. Для отримання рослинних форм із підвищеним рівнем солестійкості багато років застосовують клітинну селекцію, проте в багатьох випадках солестійкість рослин не збільшувалася [3]. Клітинна селекція як біотехнологічний метод спрямована на відбір окремих клітин зі зміненими генетичними характеристиками з подальшою регенерацією рослин. Отримані регенеранти будуть проявляти бажані, відібрані на клітинному рівні властивості та передавати їх у наступні насіннєві покоління.

Виходячи з постановки питання та враховуючи літературні дані, нами вперше запропоновано використати катіони важкого металу барію $\left(\mathrm{Ba}^{2+}\right)$ у клітинній селекції для отримання солестійких форм рослин [4]. Тютюн є типовим глікофітом. Отже, солестійкість його клітинних варіантів повинна бути доказом отримання генетично змінених форм.

Катіон $\mathrm{Ba}^{2+}$ - один 3 обмежено задіяних у наукових експериментах іонів. Це пояснюється специфічністю його впливу на біологічні об’ єкти: винятковою токсичністю для теплокровних і відсутністю в його потребі з боку рослин. Головний шкодочинний вплив $\mathrm{Ba}^{2+}$ полягає у його взаємодії з іонами $\mathrm{K}^{+}$[5-7]. Додавання лише $1 \mathrm{MM} \mathrm{Ba}^{2+}$ знижувало інтенсивність потоків $\mathrm{K}^{+}$на $30 \%$ [6]. Впливав цей катіон на експресію гена $A t H A K 1$ високоафінного транспортера $\mathrm{K}^{+}$. Із використанням лінії арабідопсису, яка мала інсерцію в тДНК, показано, що цей ген опосередковує Ва-чутливий компонент поглинання $\mathrm{K}^{+}$[7]. 3 іншого боку, установленим шкодочинним ефектом засолення $\epsilon$ саме порушення іонного гомеостазу, утрата іонів $\mathrm{K}^{+}$. Тому, ураховуючи іонний антагонізм $\mathrm{Ba}^{2+} / \mathrm{K}^{+}$, ми використали катіони $\mathrm{Ba}^{2+}$ в клітинній селекції, спрямованій на підвищення рівня солестійкості.

На селективних середовищах, до яких додавали летальні для клітинних культур дози катіонів $\mathrm{Ba}^{2+}$, виділено стійкі клітинні лінії тютюну. Вирощування стійких клітинних варіантів за різних типів засолення підтвердило висунуту гіпотезу. Під час дослідження отриманих клітинних варіантів установлено, що їхня комплексна стресостійкість реалізовувалася на фоні зростання вмісту вільного проліну [8].

Зі стійких клітинних ліній тютюну регенеровано рослини, R0, а також отримано насіннєві покоління R1, R2. B експериментах із клітинної селекції завжди актуальне повне виконання алгоритму: стійка клітинна лінія - стійкий регенерант - стійкі покоління. Лише в цьому випадку можна вважати завдання виконаним. Однак водночас відомо, що солестійкість суттєво змінюється в онтогенезі. Також існує ймовірність часткової або повної втрати бажаної ознаки. Нами раніше підтверджено солестійкість регенерантів та молодих проростків R1 [8]. Порівнянне дослідження реакцій рослин різних поколінь сприятиме подальшому розв'язанню проблеми отримання стійких генотипів.

Мета й завдання дослідження. Здійснювали тестування рослин тютюну на здатність витримувати модельоване засолення. Паралельно оцінювали вміст вільного проліну в листках стійких форм, оскільки солестійкість клітинних варіантів кореспондувалася зі зростанням рівня цієї амінокислоти. У зв' язку з цим мета роботи - порівняння реакцій стресу / солестійкості отриманих форм, а ключове завдання - установлення ролі проліну в підтриманні життєдіяльності рослин за стресових умов.

Виклад основного матеріалу й обгрунтування отриманих результатів дослідження. Об'єкт дослідження - рослини R0, регенеровані із Ва-стійких клітинних ліній тютюну, а також рослини R1, R2.

Рослини R0 до експерименту вирощували in vitro на безгормональному живильному середовищі Мурасиге-Скуга [9]. Для дослідження солестійкості регенеранти ділили на частини, кожна з яких мала по 
три листки, і переносили на це ж середовище, доповнене солями морської води (20,0 г/л). Тривалість досліду - 35 діб. За цей час у рослин R0 відновлювали ризогенезу й починали формуватися нові листки. У разі переміщення в нормальні умови процес росту та розвитку не припинявся. Така концентрація засолення була летальною для рослин контролю [8].

Рослини R1, R2 отримували, пророщуючи насіння in vitro на зволоженому фільтрувальному папері до появи корінців, а потім дорощували в напіврозведеному водному розчині макроелементів за МурасигеСкугом. Для аналізу відбирали рослини, у яких розмір надземної частини був у межах 5,0-7,0 см. Засолення створювали додаванням солей морської води (25,0 г/л); рослини витримували за стресових умов упродовж 10 діб.

Ми вважали та вважаємо, що стрес, котрий може призвести до летального результату, можуть витримати виключно генетично змінені форми. Водночас стійкість рослин проявляється не лише в здатності генотипу розвиватися за умов довготривалого стресу, але й витримувати короткостроковий наджорсткий стрес. Показником життєдіяльності вважали вміст вільного проліну, який аналізували за стандартною методикою [10]. Уміст загальних білків визначали методом Лоурі [11].

Дію абіотичних стресів можливо досліджувати в природі або моделювати in vitro. При цьому отримані в штучних умовах дані порівнюють із природною ситуацією. Засолення як стресовий чинник зі збільшенням терміну впливу викликає поширення шкодочинних порушень. Тому при встановленні факту стійкості генотипів важливо вирізняти реакції стресу від реакцій адаптації, особливо у випадку оцінювання окремих біохімічних показників. На нашу думку, неоднозначності можна уникнути при застосуванні жорсткого, краще летального, засолення. За умов in vitro рослини вирощували впродовж 35 діб. За період тестування на сольовому фоні проявилися протилежності генотипів (контролю та R0). У регенерантів відновлювався процес морфогенезу, у контрольних варіантів розвивалися стресові порушення. Про ступінь їх на 35 добу свідчить зменшення вмісту білку (табл. 1).

Татлиия 1

Уміст білку й проліну в рослинах тютюну при культивуванні in vitro

\begin{tabular}{|c|c|c|c|c|}
\hline & \multicolumn{2}{|c|}{ Нормальні умови } & \multicolumn{2}{|c|}{ Солі морської води, 20,0 г/л } \\
\hline & $\begin{array}{l}\text { пролін, }, м 2 \% / \\
\text { сир. речовини }\end{array}$ & $\begin{array}{c}\text { білок, }, м 2 / 2 \\
\text { сир. речовини }\end{array}$ & $\begin{array}{l}\text { пролін, }, м 2 \% / \\
\text { сир. речовини }\end{array}$ & $\begin{array}{c}\text { білок, }, м 2 / 2 \\
\text { сир. речовини }\end{array}$ \\
\hline R0 №13 & $53,21 \pm 4,12$ & $78,25 \pm 1,24$ & $105,09 \pm 2,21$ & $81,30 \pm 2,03$ \\
\hline R0 №21 & $24,57 \pm 3,61$ & $65,23 \pm 2,15$ & $120,441 \pm 6,12$ & $79,47 \pm 0,99$ \\
\hline Контроль & $25,10 \pm 4,55$ & $95,11 \pm 2,47$ & $55,72 \pm 4,86$ & $35,31 \pm 4,10$ \\
\hline
\end{tabular}

Водночас у всіх генотипів суттєво зростав рівень вільного проліну (табл. 1). Однак причиною цього явища були протилежні події. У регенерантів R0 уміст вільного проліну підвищувався за рахунок його синтезу, оскільки забезпечувалося підтримання життєдіяльності на фоні засолення - стабільний синтез білків (навіть на 35-ту добу). Навпаки, зниження білкового пулу в контрольних рослин ( 2,7 раза) було ознакою не лише стресового пригнічення загального метаболізму, але й може вказувати на деградацію клітинних компартментів, унаслідок чого підвищився рівень проліну.

Відомо, що серед численної групи рослинних протеїнів існують особливі, збагачені проліном (proline rich proteins, PRPs). Вони задіяні в компартментах клітинних стінок [12; 13]. У їх молекулах залишки проліну організовані в мотиви, котрі повторюються, до яких може долучатися гідроксипролін. Формуються внутрішньо- та міжмолекулярні перехресні зв'язки, що забезпечують структуру клітинної стінки. У разі порушення цілісності стінок клітин пролін вивільняється.

Отже, у варіантів тютюну спостерігали дві різноспрямовані реакції, а саме: адаптацію до жорсткого тривалого сольового стресу в рослин R0 і широкомасштабні порушення в контрольних рослин на фініші тестування. Обидві реакції супроводжувалися зростанням умісту проліну.

Протікання події оцінювали під час вивчення рослин R1 та R2 у водній культурі. Такий підхід обирали 3 двох причин. По-перше, створювали нетривалий наджорсткий стрес (25,0 г/л солей морської води), оскільки тестували сформовані рослини. По-друге, одночасно встановлювали факт успадкування ознаки в поколіннях, що є метою клітинної селекції.

Діаграми на рис. 1 відображають динаміку змін рівня вільного проліну в рослинах тютюну у відповідь на дію засолення. Усі варіанти реагували аналогічно. До п'ятої доби (включно) уміст амінокислоти в усіх рослинах не змінювався, за абсолютною величиною відповідав показникам, наведеним у табл. 1. На сьому 
добу відбувалося його суттєве зростання. Оскільки патологічна дія солі спряжена 3 проникненням токсичних іонів усередину клітини з перших днів досліду [8], то на сьому добу, імовірно, розпочиналась їхня негативна дія на внутрішні структури клітини. Це призвело до активації захисних реакцій рослин.

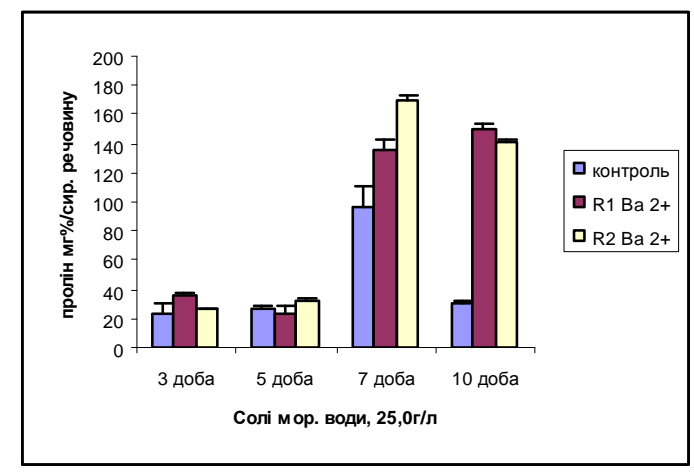

Рис. 1. Зміни вмісту вільного проліну в рослинах тютюну під час тестування у водній культурі

Серед численних властивостей проліну відзначають детоксикуючу [2]. Збільшення вмісту проліну (57 доби) відбувалось унаслідок збільшення його синтезу. На нашу думку, цей процес здійснювався у всіх генотипів. На користь цього припущення може свідчити стабільність рівня до п'ятої доби, а також присутність у водному розчині мінеральних елементів. У подальшому реакції рослин тютюну змінювались. Для контрольних рослин сьома доба була початком їх загибелі. Як указано вище, тютюн - це типовий глікофіт, для якого концентрація солі 20,0 г/л є летальною [8]. Зниження рівня проліну, яке спостерігали на десяту добу досліду, незаперечно вказує на втрату складників клітин (у тому числі проліну) через масштабні ушкодження, викликані постійним нагромадженням солі. Водночас рослини насіннєвих поколінь стабілізували свій метаболізм і підтвердили солестійкість.

Отже дія короткострокового наджорсткого засолення в рослинах тютюну викликала різні реакції: у контрольних рослин повністю порушувався метаболізм; у рослин R1 та R2 метаболізм стабілізувався й спрямовувався на підтримку організму.

Висновки та перспектива подалышого дослідження. Отже проведені дослідження підтвердили факт успадкування ознаки стресостійкості в рослин R1 i R2 тютюну. Насіннєві покоління підтримували життєздатність при засоленні, летальному для контрольних рослин. Стійкість рослин реалізовувалась in vitro та у водній культурі на фоні акумуляції вільного проліну. Клітинна селекція із застосуванням іонів $\mathrm{Ba}^{2+} \epsilon$ перспективним методом отримання рослинних форм із підвищеним рівнем солестійкості.

Високий рівень вільного проліну в солестійких і солечутливих генотипів був проявом різноспрямованих реакцій. Отже, його абсолютні значення не можуть бути однозначним показником солестійкості. Тому подальші дослідження спрямовуватимуться на вивчення динаміки змін умісту проліну, а також на дослідження успадкування ознаки в наступних поколінь рослин тютюну.

\section{Джерела та література}

1. Kishor P. B. K. Regulation of proline biosynthesis, degradation, uptake and transport in higher plants: its implications in plant growth and abiotic stress tolerance / P. B. K. Kishor, S. Sangam, R. Amruta et al. // Curr. Sci. - 2005. - 88. P. 424-432.

2. Szabados L. Proline: a multifunctional amino acid / L. Szabados, A. Savoure // Trends Plant Sci. - 2010. - 15. - P. 89-97.

3. Dracup M. Why does in vitro cell selection not improve the salt tolerance of plants? / M. Dracup // Genetic aspects of plant mineral nutrition / Eds. P. J. Randall et al. ; Kluwer Academic Publishers, 1993. - P. 137-142.

4. Деклараційний патент на винахід №44487 А01Н1/04, А01Н4/00 Спосіб відбору стійких до засолення клітинних ліній рослин / Л. Є. Сергєєва, подання 18.04.2001, опубліковано 15.02.2002, бюл. № 2.

5. Николаев Л. А. Биокатализаторы и их модели : учеб. пособие / Л. А. Николаев. - М. : Высш. шк., 1968 - 196 с.

6. Fan L.-M. Identification and characterization the inward $\mathrm{K}^{+}$channel in the plasma membrane of Brassica pollen protoplasts / L.-M. Fan, W.-H. Wu, H.-Y. Yang // Plant and Cell Physiol. - 1999. - 40, № 8. - P. 859-865.

7. Rubio F. Relative contribution of AtHAK5 and AtAKT1 to $\mathrm{K}^{+}$uptake in the high-affinity range of concentrations / F. Rubio, M. Nieves-Cordones, F. Aleman, V. Martinez // Physiol. Plant. - 2008. - 134. - P. 598-608.

8. Сергеева Л. Е. Клеточная селекция с ионами тяжёлых металлов для получения генотипов растений с комплексной устойчивостью к абиотическим стрессам / Л. Е. Сергеева. - Киев : ЛОГОС, 2013. - 211 с.

9. Murashige T. A revised medium for rapid growth and bioassays with tobacco tissue culture / T. Murashige, F. Skoog // Physiol. Plant. - 1962. - 15. - P. 473-497. 
10. Андрющенко В. К. Модификация метода определения пролина для выявления засухоустойчивых форм рода Lycopersicon Tourn / В. К. Андрющенко, В. В. Саянова, А. А. Жученко и др // Известия Академии наук Молдавской ССР. - 1981. - № 4. - С. 55-60.

11. Степанченко Н. С. Количественное определение содержания белка // Физиол. растений. - 2011. - 58. - Р. $624-630$.

12. Stein $\mathrm{H}$. Elevation of free proline and proline-rich protein levels by simultaneous manipulations of proline biosynthesis and degradation in plants / H. Stein, A. Honig, G. Miller et al. // Plant Sci. - 2011. - 181. - P.140-150.

13. Battaglia M. Proline-rich cell wall proteins accumulate in growing regions and phloem tissue in response to water deficit in common bean seedlings / M. Battaglia, R. M. Solorzano, M. Hernandez et al. // Planta. - 2007. - 225. P. 1121-1133.

Сергеева Лариса, Бронникова Лариса. Пролин-опосредованные реакции табака на действие засоления. Предметом настоящей работы было сравнительное исследование реакций растений табака на действие летального засоления и роли свободного пролина в реализации солеустойчивости.

Методом клеточной селекции с использованием летальных для клеточных культур доз катионов Ва ${ }^{2+}$, получены устойчивые клеточные линии табака. Из них получены регенеранты R0, а также семенные поколения R1, R2. Клеточные линии и растения R0, R1 и R2 отличались устойчивостью к моделированному летальному солевому стрессу. Сравнивали реакции, сопряжённые с повышением уровня свободного пролина, у экспериментально полученных растений и исходных растений табака, который является типичным гликофитом. Растения R0 культивировали in vitro в течение 35 сугок в присутствии 20,0 г/л солей морской воды; растения R1, R2 тестировали в водной культуре 10 суток, добавляя 25,0 г/л этого же вещества.

Отмечали противоположные реакции растений табака в ответ на действие засоления: контрольные растения погибали, а экспериментальные варианты стабилизировали свой метаболизм, что проявлялось в сохранении синтеза белка. В то же время во всех растениях возрастало содержание свободного пролина. Однако аккумуляция данной аминокислоты в экспериментальных вариантах была следствием повышения её синтеза, тогда как пролин в контрольных растениях образовывался при деградации клеточных белковых компартментов. Таким образом, абсолютные значения содержания свободного пролина не могут быть гарантированным показателем солеустойчивости; следует оценивать динамику его изменений.

Ключевые слова: табак, клеточная селекция, катионы бария, засоление, устойчивость, пролин.

Sergeeva Larisa, Bronnikova Larisa. The Proline-mediated Reactions of Tobacco Plants, Cultivated Under Salinity. The comparative investigation of tobacco plants reactions on lethal salinity pressure and their proline status were the objects of the research.

On selective media with the addition of lethal for cell cultures doses of $\mathrm{Ba}^{2+}$ cations resistant tobacco cell lines occurred. Regenerants R0 and seed progenies R1, R2 were obtained from those lines. Cell lines, R0, R1 and R2 plants challenged the simulated lethal salt stresses. The comparative investigation of proline-mediated reactions of those variants and initial tobacco (pure glicophyte) were elaborated. R0 plants were cultivated in vitro during 35 days on cultural media with the addition of $20,0 \mathrm{~g} / \mathrm{l}$ sea water salts; R1 and R2 plants were tested in water culture with the addition of 25,0 g/l sea water salt during 10 days.

Control and experimentally obtained variants developed different reactions to salt pressure. Control plants eliminated. Experimental variants maintained their metabolism reflected in stable protein biosynthesis. At the same time the free proline levels increased in all genotypes. But in resistant variants these events resulted from amino acid biosynthesis, while in control plants proline appearance was the result of the protein compartments degradation. So data of free proline level are not adequate markers of the plant salt resistance. There is better to estimate the character of proline changes.

Key words: tobacco, cell selection, barium cations, salinity, tolerance, proline

Стаття надійшла до редколегії 29.09.2016 р.

УДК 712.253:581(477)

Анна Савоськіна

\section{Оцінювання декоративності дендросозоекзотів штучних заповідних парків Українського Полісся}

У статті оцінено ступінь декоративності дендросозоекзотів ex situ штучних заповідних парків Українського Полісся. Для цього використано нову комплексну методику оцінки декоративності, розроблену спеціально для дендро-

(C) Савоськіна А., 2016 